\title{
Hydrodynamic features of the formation and placement of thermal waters of the Eastern Ciscaucasia and their protection from surface pollution
}

\author{
M.M. Labazanov, Z.I. Gadaeva, P.U. Musaeva, T.Kh. Ozdieva \& Z.M-E. Damzaev \\ Grozny State Oil Technical University named after Acad. M.D. Millionschikov, Grozny, Russia
}

\begin{abstract}
Using the example of the Eastern Ciscaucasia, where there are extremely favorable and at the same time contrasting combinations of geological - tectonic, hydrodynamic, geothermal, and also hydro-hydrographic conditions, it seems possible to trace the main geological and physico-chemical processes that determine the formation and distribution of various types of groundwater associated with different zones and structural - hydrogeological floors and the dependence of the degree of their protection from surface pollution in connection with these especially features.

When considering this issue, first of all, it should be noted that all the main scientific hypotheses of the formation of groundwater are not groundless and depending on the geological conditions of the region, there are various options.

In particular, there is no doubt that the fresh and weakly mineralized warm groundwater of the Tersko-Kum artesian basin and groundwater of the aeration zone of the mountain-folded regions of Dagestan, in their overwhelming part, are waters of infiltration origin.

The processing of enormous factual material on hydrodynamics, hydrochemistry, gas geochemistry, geothermy, hydrological and climatic conditions, collected from the results of drilling about 3000 artesian wells, allowed us to conclude that the Tersko-Kum artesian basin of Pliocene and anthropogenic deposits is a hydrodynamically open flowing natural system with modern natural resources in the amount of $0.6 \mathrm{~km}^{3} / y e a r$ and potential resources of about $6.0 \mathrm{~km}^{3} /$ year.
\end{abstract}

\section{INTRODUCTION}

The problem of groundwater formation is complex and multifaceted and, depending on specific environmental conditions, has common and specific features.

The results of comprehensive studies indicate that low-mineralized thermal waters of the structural-hydrogeological floor (Miocene complex) also relate to a large part to waters of infiltration origin with a certain proportion of sedimentation and elizion waters from below and, in some cases, overlying horizons.

In the thickness of the Middle Miocene sediments, aquifers with a pore nature of groundwater circulation are distinguished, the formation of reserves of which occurs at the base by infiltration of atmospheric and surface waters, which is confirmed by actual material on the hydrodynamics of the aquifer. Actual hydrodynamic data make it possible to identify feeding, discharge and discharge areas for the Middle Miocene aquifer complex and, accordingly, areas more or less potentially susceptible to possible pollution.

The feeding areas are located within a fairly wide range of outcrops of Middle Miocene deposits to the surface, stretching from west to east along the Montenegrin monocline, the Narat-Tyubinsky zone; then the strip of exits turns in a southeast direction and stretches far south, where the Middle Miocene sediments overlap with the thickness of the Akchagyl deposits, which are mismatched on the underlying ones, down to the Jurassic (Andrushchuk, 
Dubinsky, Hain, 1968). The yields of Middle Miocene sediments are located at hypsometric elevations from 200 to $800 \mathrm{~m}$ in places and more, with individual peaks up to $1000 \mathrm{~m}$. The maximum elevations of $600-900 \mathrm{~m}$, correspond to the Black Mountains, decrease to 200 $400 \mathrm{~m}$ within the Narat-Tyubinskaya zone, slightly increase in Southern Dagestan is up to 300 - $500 \mathrm{~m}$ less often than $600 \mathrm{~m}$.

In the north, northeast direction from the areas of exits there is a regional subsidence of the strata. The roof of the Middle Miocene deposits is located at depths: in Makhachkala 800-1200 m, Ternair - 800-1000 m, Izberbash - 400-800 m, Karanai-Aul syncline $1600 \mathrm{~m}$, Bilgadi syncline - 400-600 m, in Derbent - $950 \mathrm{~m}$. V the zone of maximum subsidence in the Tersko-Caspian trough, the roof of the Middle Miocene deposits is located at depths of 3,500 - 3,700 m (Kurush, Karamay) i.e. the water of these deposits is almost completely protected from surface pollution (Figure 1).

Thus, based on the classical representations of artesian basins, the difference in the hydrostatic sets of supply areas and wellheads in the transit areas reaches the first tens of atmospheres, which should practically ensure water self-discharge in the overwhelming part of the distribution area of the Middle Miocene aquifers, taking into account hydraulic resistance. In fact, self-draining waters are ubiquitous.

The exception may be some areas where deep erosion valleys drain the Middle Miocene deposits, because of which natural depression extends to aquifers within the first tens of kilometers (Andrushchuk, Dubinsky, Hain, 1968). Such conditions are available in areas adjacent to the river valley. Sulak and other foothill rivers that drain these deposits at elevations of $100-300 \mathrm{~m}$, as well as near feeding areas.

In the areas of runoff and transit, which cover all the territories of the Forward Trough, the Kumskoy and Tersko-Sulak plains, the piezometric surface is characterized by a general drop in

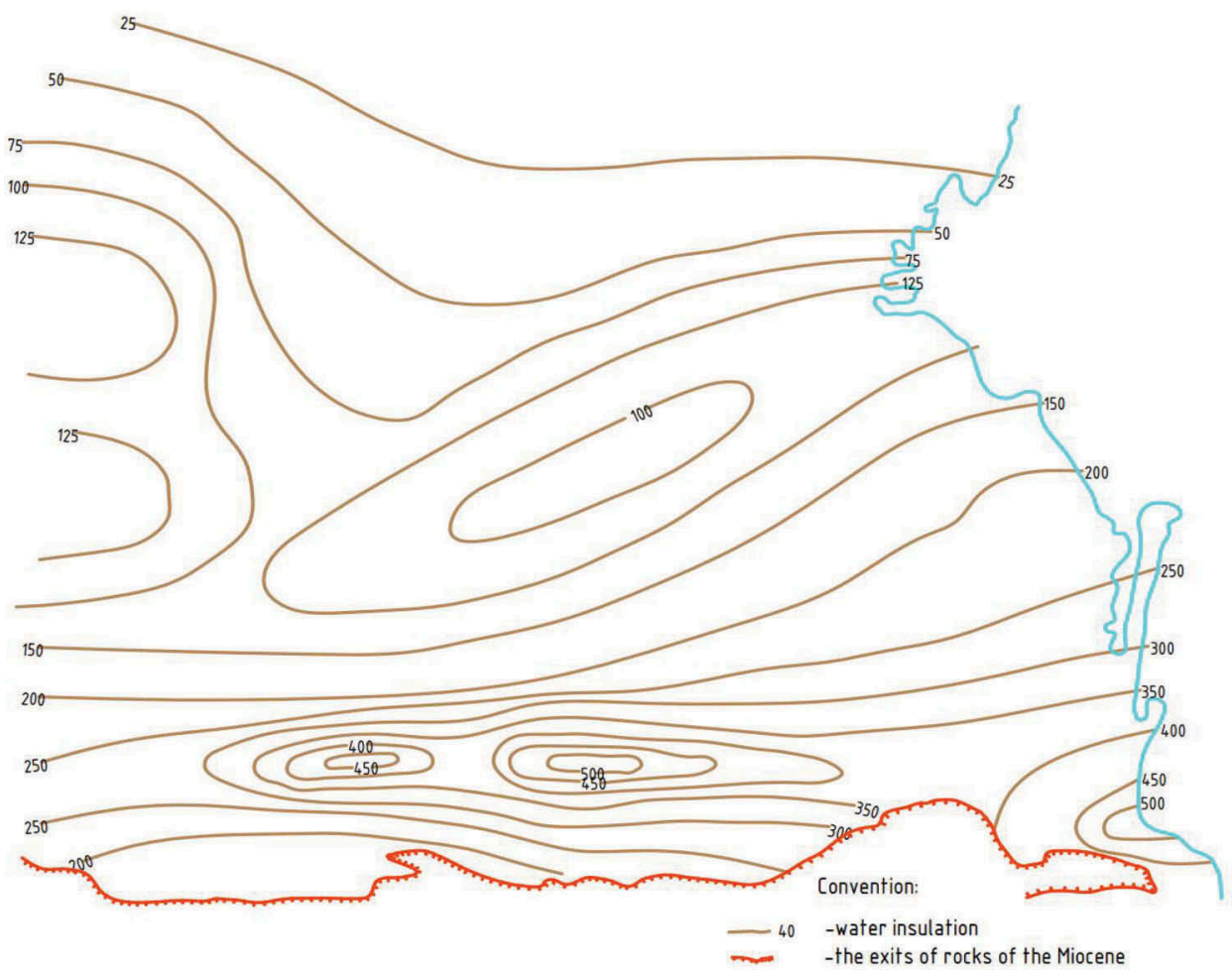

Figure 1. Schematic map of the conductivity of the Middle Miocene aquifer. 
the pressure of water in the directions from the feeding areas to the north and northeast towards the Caspian Sea, consistent with the regional dip in the north - east and east.

Absolute elevations of piezometric levels vary from $200-500 \mathrm{~m}$ in areas directly adjacent to food areas, to $10-150 \mathrm{~m}$ in areas remote to significant distances from them. (Table 1). The relative elevation of the hydrostatic level increases from the first units of meters to 14-16 atmospheres in the Makhachkala, Kizlyar, Northeast of Kizlyar in the areas of TerekliMekteb - Chervlennye Buruns, hydrostatic pressure at the mouths drops to 10-8 atmospheres.

Actual material on the hydrodynamics and hydrochemistry of Middle Miocene deposits allows us to distinguish three hydrodynamic zones - active, slow and very slow water exchange, which therefore are logically subdivided into three zones of protection from surface pollution.

The zone of active water exchange includes the piedmont regions of the Eastern Ciscaucasia, composed of middle-price deposits entering the day surface with hypsometric marks 200-600 mine and deep erosion valleys, which serve as local erosion bases. This zone is characterized by maximum hydraulic slopes of 0.01-0.03, filtration coefficients (average) of 4.0-5.5 m/day, and filtration rates of 4-17 cm/day. or 15-62 m/year. In hydrochemical terms, this is the zone of maximum washing with fresh and slightly mineralized waters of hydrocarbonate, sulfate and mixed chemical composition.

Of the cations that determine the chemical composition, $\mathrm{Ca}$ and $\mathrm{Mg}$ prevail, and the anions are sulfates and bicarbonates.

The high hypsometric position, the presence of a rather dense river network, rugged terrain, and an abundance of precipitation with favorable lithological-facies and geomorphologicaltectonic conditions contribute to intensive circulation and active groundwater exchange. In this case, the role of the distances from the supply area to the discharge area, which are minimal in this area, is significant. The upper hydrodynamic zone is represented by ground lowpressure and pressure fresh and low-mineralized waters. Numerous springs are confined to the Middle Miocene deposits in river valleys and natural relief depressions.

Numerous artesian and structural mapping wells have been drilled in the active water exchange zone, which reveal aquifers at depths from $50-60 \mathrm{~m}$ to $300-500 \mathrm{~m}$ and produce in most cases self-flowing waters with flow rates from fractions up to $2-151 / \mathrm{s}$. The reservoir properties of the sandstones of the active exchange zone are quite high. The porosity in the Sulak basin is from 14 to $23.6 \%$, an average of $18-20 \%$, the permeability is very high from units to 8-10 darsi. (Mironenko, 2001).

In general, the zone of active water exchange is characterized by significant groundwater circulation rates, hydrogeological flushing of rocks and, as a result, low water salinity, the

Table 1. Absolute elevations of piezometric levels.

\begin{tabular}{llllll}
\hline REGION & $\begin{array}{l}\text { №o } \\
\text { well }\end{array}$ & $\begin{array}{l}\text { Abs. Wellhead } \\
\text { marks }\end{array}$ & $\begin{array}{l}\text { Perforation } \\
\text { interval }\end{array}$ & $\begin{array}{l}\text { Deposits } \\
\text { age }\end{array}$ & $\begin{array}{l}\text { Abs. piezometric } \\
\text { level marks }\end{array}$ \\
\hline 1 & 2 & 3 & 4 & 5 & 6 \\
\hline Agach aul & 1 & 264,2 & $308-316$ & Karagan & 210,5 \\
Kaka-yurt & 7 & 207,1 & $203-215$ & “ & 213,6 \\
Ternair & 20 & 2,25 & $1085-1110$ & “ & 92,2 \\
Makhachkala & 160 & -20 & $1487-1518$ & “ & 70,0 \\
Bunaysk & $1-56$ & 557,0 & $77-93$ & “ & 558,65 \\
Gerga & $6-T$ & 50,8 & $1388-1405$ & “ & 53,1 \\
Manas Kent & $10-T$ & 36,18 & $1547-1561$ & Karanay & 51,18 \\
Manas Kultun & $9-\mathrm{T}$ & 10,6 & $1414-1448$ & “ & 32,6 \\
Kaspiysk & $2-\mathrm{T}$ & $-18,48$ & $1482-1492$ & “ & 32,78 \\
Derbent & $11-\mathrm{T}$ & $-14,77$ & $1260-1278$ & “ & 24,43 \\
Kizlyar & $4-\mathrm{T}$ & $-4,8$ & $2786-2824$ & “ & 135,2 \\
Kraynovka & 1 & $-20,0$ & $2146-2148$ & “ & 60,0 \\
\hline
\end{tabular}


predominance of calcium sulfates and bicarbonates, and a pronounced oxidative state. Flow rates, pressures, temperatures and composition of water, especially sources, are subject to seasonal fluctuations. The zone of active water exchange is the zone most susceptible to pollution.

The zone of delayed water exchange includes the water horizons of the Middle Miocene deposits located at depths from 400-500 to 2-3 thousand meters, which covers the vast majority of the study area. This zone includes the foothill and plain parts of the basin, which includes all thermal water deposits: Makhachkala, Izberbash, Kayakentsk, Kizlyarsk, Tarumovskoye, Terekli-Mektebskoye, Cherlennye Burun, Groznenskoye, Khankala and others. The regime of water horizons is characterized as a water head with estuary pressures 2-3 to 14-16 atm. Waters are self-draining throughout the territory, water flow rates are incomparably higher than in the first zone and reach up to $2-3$ thousand $\mathrm{m}^{3} /$ day.

In general, for the southern part of the basin, filtration rates are $2-3 \mathrm{~mm} /$ day or $0.7-1.0 \mathrm{~m} / \mathrm{year}$.

The fall of piezometric levels occurs in the northern, northeastern and eastern directions, from 180-200 m. Near nutrition areas to $10-30 \mathrm{~m}$ in Southern Dagestan and 80-100 m in Northern Dagestan. The gradients of the piezometric levels are maximum in the foothills of Southern Dagestan from 0.007 to 0.24 , in the foothill zone of Northern Dagestan from 0.012 to 0.05 . As you move north in the platform part, minimum speeds are noted and hydraulic gradients here are $0.001 \mathrm{~m}$ or less (Ovcharova, 2009).

As aquifers sink, formation pressures, hydrostatic pressure and water temperature increase. The zone of delayed exchange is hydrochemically characterized by the presence of chloridehydrocarbonate, chloride-sulfate sodium water. Mineralization of water gradually increases with depth to $10 \mathrm{~g} / \mathrm{l}$, and in some areas and formations to $30 \mathrm{~g} / \mathrm{l}$.

The zone of delayed water exchange is distinguished not only by the features of hydrodynamics and hydrochemistry of waters, but by the conditions of formation and regime of groundwater. The zone under consideration is characterized by relatively sustained thickness of aquifers, most often represented by small- and medium-grained sandstones of low cementation. As you move from the feeding areas deep into the flat part, the water regime gradually becomes stationary. Flow rates, pressures, chemical composition, temperatures are not subject to seasonal, annual and numerous fluctuations.

In general, the reserves and resources of this zone are incomparably large relative to the zone of active water exchange, which is explained by the maximum elastic reserves that can be exploited for apparently decades and are practically not subject to surface pollution.

The zone of a very slow water exchange includes the conditionally most submerged part of the Tersko-Caspian piedmont deflection, which is characterized by the presence of highly mineralized chlorine-sodium type in the Midiocene aquifer complex. Huge geostatic pressures contribute to a decrease in porosity, which determines the stagnant nature of the fluids. Unfortunately, this entire zone was not covered by drilling, and the only Karaman-I well drilled here in the southern geosynclinal board passed the very top of the Karagan Formation. This area is completely protected from surface contamination.

\section{CONCLUSION}

Thus, the underground waters of the Eastern Ciscaucasia according to their geological conditions of formation and occurrence are divided according to the degree of protection from surface pollution into 3 zones: unprotected; practically protected, but with the likelihood of contamination and fully protected.

The following tasks in the field of studying and developing the geothermal resources of the region, the authors consider:

- complex geological and geophysical, geochemical, geothermal, hydrogeological and experimental studies to prove and confirm the presence of depths of the hydrogeothermosphere, which should serve as a practically inexhaustible source of geothermal energy and valuable hydromineral raw materials;

- studies on practical confirmation and experimental proof of the possibility of implementing a self-circulating geothermal system and the growth of its effectiveness with depth. 
It is known that there are "hot spots" on Earth that are hotbeds of fresh mantle jets; therefore, there should also be "cold spots" that should serve as large foci of infiltration of water resources to great depths. Perhaps they are decompressed zones of spreading in mountain folded areas of land and ocean. In theoretical terms, the problem of heat and mass transfer of the upper horizons with deep bowels deserves attention the problem of finding "cold spots", the existence of which is evidenced by a number of factors.

In the scientific, methodological and applied respect, the creation of a bank of geological and all parameters of gas-oil, geothermal and artesian wells of the basin, the creation of a hydrogeological balance model for managing geothermal resources of the East Ciscaucasia basin based on geoinformation modeling is of great importance.

In the matter of further rational development of geothermal energy and raw material resources, scientific and methodological studies on the development of multilayer geothermal deposits, improvement of the designs of geothermal production and injection wells, and the development of a model geothermal heat supply system, including underground and all ground circuits, as well as water treatment and pumping them back into the reservoir.

\section{REFERENCES}

Andrushchuk V. L., Dubinsky A.Ya., Hain V. E. 1968. Geology of the USSR. Volume 9. Northern Caucasia Part 1. Moscow: Geological description of the Subsoil

Borovikov A. A. Vasilieva N.V., Leiko D. M. 2018. Engineering Geology and hydrology. Moscow: BGCKHA chute.

Davis S. de Whist R. 1970. World. Hydrogeology. Moscow

Dvorov I.M., Dvorov V.I. 1976. Enlightenment. Thermal waters and their use. Moscow

Everett L.G. 2004. Groundwater resources of the world and their use United Nations Educational Scientific and Cultural Organization. Paris.

Kartsev A.A., Vagin S.B. Shurygin V.P. 1992. Subsoil. Oil and gas hydrogeology. Moscow.

Kovyatkin L.A., Matusevich V.M. 2010. Oil and gas hydrogeology. Part 1. Theoretical foundations of oil and gas hydrogeology. Tsogu, Tyumen.

Mironenko V. A. 2001. Dynamics of underground waters. Moscow: Moscow state mining University.

Ovcharova T. A. 2009. Hydrogeology. Ukhta: UGTU.

Cherkashin V. I., Mamaev S. A., Magomedov R. A., Isaeva N.A. 2015. Geology and resources of Dagestan. Makhachkala.

Vagin S.B., Kartsev A.A., Shugrin V.P. 1992. Nedra, Oil and gas hydrogeology. Moscow.

Vsevolzhsky V.A. 2007. Tutorial. 2nd ed. MSU Publishing House. Fundamentals of hydrogeology.

Vsevolozhsky V.A. 2007. Moscow State University. Fundamentals of hydrogeology. Moscow 